\title{
EEN BELANGRIJK DAGBOEK
}

\author{
DOOR
}

MR. B. DE GAAIJ FORTMAN

De bekende Curaçaosche geschiedvorscher Pater P. A. Euwens O. P. vestigde geruimen tijd geleden mijne aandacht op een handschrift, door de Belgische hoogleeraren De Lannoy en Van der Linden in hun werk Histoire de l'expansion coloniale des peuples Européens-Neerlande et Danemark (XVIIe et XVIIIe siècles) als geraadpleegd vermeld, zich bevindende in de Universiteitsbibliotheek te Gent, en getiteld: Journael wegens de comste en onderneminge der france vloot onder 't Commando van Mons. Cassard voorgevallen op Curaçao. Het heeft mij weinig moeite gekost om door vriendelijke bemiddeling van den welwillenden Dordtschen archivaris, den heer J. L. van Dalen, het handschrift op zijn archief ter raadpleging te krijgen. Al spoedig bleek het mij een belangrijk geschrift te zijn, dat tot nu toe onbekende gegevens bevat omtrent de overigens zeer bekende brandschatting van het eiland Curaçao door den Franschen admiraal Jacques Cassard in 1713.

Hamelberg putte voor dit gedeelte zijner geschiedenis van de Nederlanders op de West-Indische eilanden ${ }^{1}$ ) uit den brief, die de gouverneur Jeremias van Collen op 28 Maart 1713, na het vertrek der Franschen, aan de X richtte; in hoofdzaak gaf hij alleen dien brief weer, daar het hem blijkbaar onaangenaam was, deze donkere bladzijden van Curaçao's geschiedenis met eigen woorden te beschrijven. Aan de reeds in het Eerste jaarlijksch verslag van het Geschied-, taal-, land-en volkenkundig genoot-

1) II bladz. 119-126. 
schap te Willemstad (1897) afgedrukte Notulen van den Raad van 16 Februari tot 23 Maart 1713 voegde hij tevens de volgende Documenten toe: eenige brieven, tusschen Van Collen en Cassard gewisseld, de voorwaarden der brandschatting, den omslag van het bedrag der te betalen som over de ingezetenen, eenige gegevens omtrent gewonden, een Relaas van het voorgevallene en journaal van de Heeren De By en Horst en een kort uittreksel uit den brief dd. 17 Mei van den fiscaal Van Halmale aan de W. I. C.

Aan bovengenoemde notulen van den Raad, rechtstreeks of zijdelings, hebben Teenstra ${ }^{1}$ ) en Simons ${ }^{2}$ ) hunne mededeelingen ontleend. $\mathrm{Bosch}^{3}$ ) daarentegen, die hun voorafging, vertelt, dat hem een oud manuscipt was ter hand gesteld, ,een vers, waarin op eene satirieke wijze de daden bezongen werden dier helden, welke ,bij de landing van $\mathrm{D}$ e C a s s a rd, met zoo vele zorg hun leven voor het land bewaard hadden. Daaruit bleek het, dat de gezagvoerenden in plaats van de zeelieden voor zich te winnen en aan te moedigen hen beleedigden en onwillig maakten, in plaats van tijdige maatregelen te nemen, om den landenden vijand afbreuk te doen, de voorslagen daartoe, of geheel van de hand wezen, of door dralen verwaarloosden; en in plaats van een voorbeeld van dapperheid en zelfopoffering te geven, het eerst den vijand de hielen lieten zien, en lafhartiglijk de vlugt namen". De schrijver wijst hierop in tegenstelling met den indruk, die de notulen geven, waarin de schuld gegeven wordt , aan de onverschilligheid van het zeevolk, in hetwelk, door de vele vaartuigen, die ook toenmaals in de haven lagen, de kracht tot verdediging gelegen was." Het is wel jammer, dat Bosch uit den inhoud van dit handschrift niets meedeelt.

Intusschen zal men ook uit het hier volgende Journael

1) M. D. Teenstra, De Nederlandsche West-Indische eilanden in derzelver tegenwoordigen toestand, tweede stuk, 1837, bladz. 35 e.v.

2) G. J. Simons, Beschrijving van het eiland Curafou, uit verschillende bronnen bijeenverzameld, 1868, bladz. 38 e.v.

$\left.{ }^{3}\right)$ G. B. Bosch, Reizen in West-Indië, en door een gedeelte van Zuid-en Noord-Amerika, eerste deel, 1829, bladz. 278 e.v. 
zonder twijfel een anderen indruk krijgen, dan de directeur Van Collen aan de bewindhebbers der W. I. C. meende te moeten geven. Men lette eens op wat het Gentsche journaal zegt over de gezindheid der burgerij en der scheepskapiteins op 28 Februari om aan den eisch van den Franschen afgezant toe te geven; over den aandrang, door den gouverneur op 2 Maart uitgeoefend op de kapiteins, burgerofficieren en kooplieden om den vijand ,af te zetten met een Goudbeurs van P. 60 000", en diens houding den volgenden dag; over het gebrek aan kogels bij de Franschen, hunne onbruikbare mortieren (4 en 5 maart), en afgedekte hoopen bommen (3 Maart), over het loslaten der krijgsgevangenen op 1 Maart op bevel van den gouverneur, en vooral op de verhalen der Fransche officieren, toen de zaak reeds beklonken was (6 Maart).

De belangwekkende vraag wie de maker van dit dagverhaal wel mag zijn, kan ik niet beantwoorden. Een officieel rapport zal het vermoedelijk niet zijn, daar het dan niet licht zou ontbroken hebben onder de officieele stukken, die Hamelberg vond in de archieven, en in zijne Documenten geheel of bij uittreksel openbaar maakte. Daartegenover staat, dat het reeds zoo vroeg begint, November 1712, hetgeen erop schijnt te wijzen, dat wij hier te doen hebben met een dagboek van iemand, die, zoo al niet verplicht, dan toch gewoon was, een dagregister te houden. In ieder geval is de schrijver bijzonder goed ingelicht geweest. Bewijs daarvoor is de nauwkeurige opgave van de bezetting der buitenposten langs den zuidkant van het eiland en in de stad, die in geen der andere rapporten voorkomt. Merkwaardig is ook de gedetailleerde opgave van binnengekomen schepen, de lijst van de door het bombardement ingesloten en beschadigde huizen en die van de gewonden.

De plaats in dato 19 en 20 Febr., waar de schrijver het heeft over ,onzen" kapitein of vaandrig van de burgerij geeft niet voldoende licht.

Het is intusschen niet de brief van 17 Mei 1713 van den fiscaal Van Halmale, waarvan Hamelberg een paar regels 
meegedeeld heeft. Deze brief komt in zijn geheel zeker ook voor openbaarmaking in aanmerking.

Ik heb naar aanleiding van de andere hierboven genoemde bronnen het dagboek, dat in kleineren tekst gedrukt is, hier en daar van eene aanteekening voorzien. De eigenamen, die bijna overal verbasterd zijn en meer dan eens op verschillende wijzen, heb ik in het dagboek tusschen [ ] verbeterd overeenkomstig de reeds vermelde lijst van den omslag der aan Cassard betaalde som over de ingezetenen. Op dezelfde wijze heb ik korte verklarende opmerkingen in den tekst opgenomen.

Onder „Hamelberg” zonder meer is te verstaan zijn De Nederlanders op de West-Indische eilanden II, onder „Hamelberg Documenten": Documenten behoorende bij „De Nederlanders op de West-Indische Eilanden II Curaçao, Bonaire, Aruba, terwijl met „Notulen” die van den Raad bedoeld zijn, zooals zij van 16 Februari tot 23 Maart 1713 afgedrukt zijn als bijlage A van het Eerste jaarlijksch verslag van het Geschied-, taal-, land-en volkenkundig genootschap, gevestigd te Willemstad, Curaçao, I897.

Ao. 1712

2 9ber Woensdag

Arriveerden 3 Scheepen die gedestineert waren naar Zuriname maar door dien het zelve beleegert was, genoodzaakt om alhier te komen namentlijk 't Schip De Agata Capt.: Casper Kijsbergen [d'Agatha, kapt. Caspar Keijsberg], de Georgie de derde Capt.: Pieter Verwen [George de Derde, kapt. Pieter Verwer] en de Vrijheit, Capt. Jan Schouten [de Vrijheijt, kapt. Hendrik Schoute].

van den $3^{\text {en }}$ tot den $15^{\text {en }}$ dito

Niets zonderlings gepasseert als datter een Placcaat wierd gepubliceert dat een ijegelijk zig moeste verzien van water en branthout voor 3 maand.

16 dito Woensdag

Arriveerden het schip de Ste. Clara Capt.: Jan Joorisz Strijt [St. Claara, kapt. Jan Joris Strijt, van de W. I. C.] mede met slaven gedestineert na Suriname maar komende bij de Motkriek wiert hij een peniaag [péniche (Fr.) - bewapende sloep?] gewaer dewelke gezonden was van den heer Gouvern. om hem te advisee- 
ren alsdat de francen daar waren om het lant in te neemen maar dat het fort nog niet over was.

De Motkreek is een der naar het Noorden loopende, in zee uitmondende kreken van Suriname.

Van den $16^{e} \mathrm{~d}^{\mathrm{o}}$. tot den 3en Xbr.

Niets bijzonders voorgevallen dat waardig is om te noteeren.

Van Collen had intusschen den 29sten November aan de Praesidale kamer te Amsterdam kennis gegeven, dat de vloot van Cassard naar Suriname was vertrokken, en dat hij deFuiken de Piscaderisbaai had doen versterken, en alles in het werk had gesteld, om niet overrompeld te worden en weerstand te kunnen bieden („Hamelberg” bladz. 119).

Ao. 1713

9 Januarij

Maandag Arriveerden een barcq van St. Thomas Schippr. Jan Olij bragt de tijding als dat tot Martenico [Martinique] een Esquadre van 7 scheepen en 15 a 16 barq. gereet lagen tot de Expeditie op Curaçao te onderneemen, waar op men alles tot defentie klaar maakte, ende wierden de scheepen geordineert om langs de wal te halen, uijtgezeijt [uitgezonderd] de Capt.: Crijtberg [Keijsberg?] en Verwen [Verwer] die voor aan de mont van de haven wierden geleght om die te sluijten het placcaat van zig van water en branthout te verzien wierd wederom gerenoveert, ende nog een Placcaat afgekondigt dat ijeder borger perzoonlijk zijn wagt zoude waarneemen zoo wel Contribuanten [zij, die de wacht afkochten] als die de wagt dagelijx waarnamen op de verbeurte van thien pezos van agten moetende 2 corporaalschappen de wagt houden om de $4 \mathrm{e}$ wagt, Een van dezelve op de hoofdwagt aan de Stadspoort en d'andre in $3^{\mathrm{e}}$ verdeelt op de forten Schrickenburg, bloetfort en Oranjefort.

Cassard was na de brandschatting van Suriname en Berbice naar Martinique teruggekeerd (Hamelberg" bladz. 120) 1 peso van achten was ongeveer $f 2.50$.

De forten Schrikkenburg, Bloedfort en Oranje waren stadsforten, men vindt ze op het „Plan van het Fort „Amsterdam en de Willemstad” bij „Hamelberg” naast bladz. 174.

\section{Dingsdag}

Wierd de voorschr. Jan Olij wederom permissie verleent om te mogen uijtzeijlen omdat denzelven expres was afgezonden om advertentie aan ons te geven waar wierd op alle de andere vaartuijgen 't zy van wat natie beslag gelegt van niet te mogen vertrecken. 
De op de kust vertoevende barken waren terug ontboden („Hamelberg” bladz. 120).

11 en 12 dito

Niets notatu dignum voorgevallen.

\section{3 dito Vrijdag}

Arriveerden capt.: Pieter Pietersz bijlevelt [Bijleveld] met een france prijs zynde een leege barcq van het Esquader voorndt. gedestineert na Guadeloupe om volk te werven tot de voorschr. Expeditie, door eenen Mons. La Maare frans colonel gecommandeert en bequamen met denzelven tijdingh dat den Generaal Mons Cassar [Cassard] Zuriname had gerantsoeneert voor agt maal honderd duijzent guldens.

De brandschatting van Suriname had bedragen f. 747.350.Sur. of $f$ 622.800.- Ned. Crt. Zie West-Indische Encyclopaedie sub voce brandschatting.

14 en 15 dito

Niets notabels gepasseert.

16 dito Maandag

Arriveert de hoeker de Dorothea Capt: Josua van der doos [Josia van der Doos], komende uijt Jerlant.

17 tot 23 dito

Niets bijzonders voorgevallen.

24 dingsdag

Arriveerde Capt.: Michiel Ottamende beneffens een france prijs zynde een bercquentijn [bergentijn, brigantijn, licht (oorlogsof) vrachtschip] geladen met witte suijker snuijfftabak en cacao, van Martenico [Martinique] na Vrankrijk gedestineert waar mede men tijding bequamen dat de francen alle dagen te verwagten waren bestaande in 7 scheepen en 8 barcken te zamen omtrent 1800 man zoo militie marines als flibustiers.

25 dito tot 2 february

zijn meest aan alle de baaijen van dit Eijland volgens ordre van de $\mathrm{Hr}$. Gouverneur met inwoonderen, habitanten en vrijwilligers en slaven de wagt gehouden bij daag en nagt mitsgaders partij gehuurde matrozen onder de volgende commandeurs als teweeten aan de fuijkebaij [Fuikbaai] (alwaar kortelings te vooren een kleen halvemaantie [voorschans in den vorm van een halvemaan] van 6 stucken canon 6 ponders was gemaakt) Jacobus Saunsliefer [Zaunslifer] Cornet als open [opper?] commandant aldaar met omtrent 20 Comps: gagietreckende Ruijters en in circa 25 vrijwilligers alle te paart. 
de Capt. of schippers van barcquen van dit eyland navigeerende als Janne backer [Johannes Backer], Willem Web, Jacob Hop [Hoppe] en Coenraad Huijbeling te zamen met omtrend 150 man als mede in circa 200 vrijneegers als Lijffeijgene met haar officiers omtrend 200 man, en bij de mont van dito fuijk lag een barcq met steenen gevult om ingevalle eenig vaartuijg daar wilde inkomen dezelve te laten zinken om hetzelve te beletten Jacobus de Meij het gezag hebbende neffens den Cornet en principaal oover de negros slaven aan voorn. ${ }^{\text {den }}$ baaij -

Aan de booke [boca - mond, baai] van $S^{\text {te }}$ Barber[a of Spaansche water] lagen gecampeert de Capt: of schippers Pieter Pietersz Bijlevelt, Michiel Ottamendes en Lourens brant met te zamen in circa 150 man by haar hebbende eenige bassen [klein scheepsgeschut].

Aan het fort Caracques baij [Caracasbaai] lag den Commandeur Jacobus Zemeret met omtrend 25 zoldaaten, eenige conestapits [constabels?] en bosschieters [artilleristen], geassisteerd met Capt: Jan Joorisz Strijt beneffens in circa 40 matroozen van de Comp. slaafscheepen komende [kunnende] die manschap van de fuijk en booke van $S^{\text {st }}$ Barber[a] in Cas van attaque onder dito fort retireeren en helpen secondeeren.

Aan de Cornetsbaij [Koraal Specht of Cornelisbaai?] anders Maripompoen [bij Vianen] Lagen omtrend 40 Israeliten op een hooge berg gecampeert onder commando van Mordochaij Henriquez als capitijn, hebbnde tot haar verschansingen eenige brooten meelvaten met steenen en gront gevult, egter door de hoogte van de bergh waren genoegzaam schootvrij voor 't canon van passeerende scheepen. -

Aan de Lijpunt van Caracquesbaij tegenover de fortresse van dito baij, op een hooge bergh alwaar den opgangh zeer difficiel was voor een man te paart, waaren verscheyde hoopen steenen gelegt op de wijze als trencheen[trankeer,trinchera -loopgraaf,verschansing] omtrend 20 treden van malkanderen bequaam om de vijand aldaar het Landen te beletten in dien dezelve met kleene vaartuijge aldaar wilden passeeren zijnde de werkslaven gecommandeert en dito trencheen geordineert door Mr. Willem Meijer.

Aan de baay van Piscaderis beneden de haven maakte men een batterij aan de oostkant van de baaij van 6 a 8 stucken canon om het landen van den vijand aldaar te beletten, de volgende Capts: off schippers lagen aldaar aan de baaij gecampt met omtrend 80 man en omtrend 50 negros als capt. Secq. Everith, Gaspar de Quiriasi [de Guirigason] Juan de lapenja [de la Pina] Willem de Groot, hebbende een weg of passagie gemaakt om 
oover de booke naar Ste. Michielsbaay te konnen marcheeren.

Aan de baaij van $\mathrm{S}^{\text {te }}$, Michiel,was meede een batterij gemaakt van 12 stucken canon aan de oostzijde langs de baaij waar van den opper-commandeur was eenEngelsche commissievaarderzijnde een molat genaamt .... ${ }^{1}$ ) fernandes anders door de wandeling Capt. Pattje [Patjé] ${ }^{2}$ ) met omtrent 60 Engelsen, ende naast hem hadde commando Gerrit van Uijtregt ende onder hem Daniel Hoffman [Hofman] over eenige negros het gebied hebbende beneffens verscheyde boeren offte planters ende omtrend 25 man jonge inboorlingen off Crioolen.

Aan de westkant van $d .^{\circ}$ baay boven op een bergh waren eenige hoopen steenen als bij manieren van trencheen om de gansche baij met handgeweer te konnen begaan met schieten, en aldaar lagen gecampeert omtrend 30 man zoo planters als jonge gasten onder commando van frank Kinnegem beneffens eenige negros slaven

de verdere baaijen tot beneeden toe waaren als doe nog geen geschut gebragt nog eenige sterktens gemaakt.

Aan de fortresse van het Waterfort tot aan de ooverzijde van de haven was een sware ijzere kettingh geschooren beneffens Een cabeltouw waar nevens eenige balken en twee vlotten waaren vast gemaakt om den vijand te beletten van daar niet in te konnen komen hebbende Capt.: Kaspar Kijsberg bij indispositie van Capt. Cornelis van de Weteringe [van de Weetering] daar oover de directie en commando.

Binnen de fortresse rondom de muuren langs de gordijnen [hoofdwal tusschen twee bolwerken] alsmede in de stadt aan de Landkant waaren masten en rees [ra's] gelegt om soo het scheen den vijand het stormen te beletten.

Agter de fortresse aan de zeekant had men een loose trenchee gemaakt van klipsteenen van omtrent 4 voeten hoogte op malkanderen gelegt en met eenige schietgaten, in dewelke eenige onbruijkbare stucken canon en partij afgezaagde balken waren geplaatst.

Item buijten de stadspoort aan de zeekant, alwaar men zeyde volk met canoos aan lant konde koome, practizeerde Capt. Jan Martin [Jan Martensz?], een van steen en klij gemaakte trenchee omtrend 20 treeden lank, 14 voeten hoog en 3 voeten breet, daar in 2 stukgaten daer egter geen canon voor geplant is geweest.

Een inham genaamt de Kriek boven Altena wiert goed gevonden om te dempen alsoo men voorgaf dat men daar met kleene

1) In het handschrift open gelaten.

2) Hij werd volgens „Hamelberg Documenten” gewond aan de knie. 
barken en canoos volk kon de aan de wal zetten dog zulx is niet voltooijt.

Dit is de gedeeltelijke uitvoering van een besluit van den Raad om „de Fuik-, Caracas-, Cornet-, Piscaderis-, St. Michielsen Varsche baai met omtrent 800 man te bezetten, allen voorzien van behoorlijk geweer en van de noodige ammunitie van oorlog en vivres; de genoemde Cornet-, St. Michiels- en Varsche baai te doen versterken, en aan al de planters in de Westdivisie te bevelen om de St. Kruisbaai in staat van verdediging te brengen, teneinde den vijand het landen te beletten", zooals Van Collen aan de X in het kort schreef.

Wel geteld waren het ruim 895 man, t. w. : aan de Fuikbaai:

aan Sta. Barbara: aan Caracasbaai:

aan de Cornetsbaai: aan de Piscaderisbaai:

aan de St. Michielsbaai:
45 ruiters,

150 matrozen,

200 vrijnegers en slaven,

150 matrozen,

25 soldaten,

40 matrozen,

40 Israëlieten,

80 matrozen,

50 negers,

60 Engelschen,

25 Creolen,

30 planters en ,,jonge gasten"

Over de bezetting en verssterking van de Vaersenbaai ter hoogte van de Groote Berg wordt hier niet gesproken.

Over den ijzeren ketting zie men „Hamelberg” bladz. 107 en 108. Cornelis van de Weetering was kapitein van het compagnieschipAdrichem. Volgens het op 9Januari vermelde lag in den havenmond behalve Keysberg met d'Agatha Verwen met de George de Derde.

Van Collen liet op het bovenaangehaalde volgen: „Aldus hadden wij ons gereed gemaakt tot een dappere en vigoureuse [ [rigoureuse?] defensie en volgens gedachten van een ieder zou dan ook een vijand onder Godes zegen onverrichter zake weer moeten vertrekken”. Inderdaad - bij een „dappere en rigoureuse defensie" ware dit te verwachten geweest.

3 dito Vrijdag.

Kwam voor de fuykebaay een barcq waar op een schoot (om zyn cano uyt te zetten wierd gedaan) de welke daar op binnen roeijden inhebbende Mons: Chabert zeggende van Laguaijre [La Guayra] te komen en dat men daar niet dan oude tijdinge van Marteniko hadde en men niet geloofde dat de francen eenig desseyn hadden om alhier iets te onderneemen (schoon men naderhand vernomen heeft dat de france vloot daar alreets lag) en 
dat desEd.Comps. barcq (die aldaar omtrend 3 maanden lank met 70 man compagnies bosschieters en matroozen van de 2 Compagns. scheepen in civiel arrest had gelegen) meerendeeis volladen was, dog dat Mons: Chouaio dezelve quasi niet konde afzenden bevoorens tijding hadden hoe het met den toestand van 't eijland gelegen was, dito bercq is dien zelven dag leeg binnen gekomen, dat aan de burgerij vrij wat nadenking cauzeerde, ende sommige deed zeggen, dat gemelde Chabert een spion was, te meer denzelven kragtig aanhield om cito weder te vertrecken.

omtrent voorsz. tijd is het placcat geaffigeert met verbod van een eeuwig silentium of arbitrale correctie tegens die geene die zonder bewijs, quamen te uytten dat Chabert een spion was.

4 en 5 dito.

Niets bijzonder gepasseert.

6 dito Maandag.

Arriveerden een Engelsche barcq tijding brengende dat de Ruijters en Indianen [van Bonaire?] hem hadde toegeroepen datter 16 zeijlen Francen aan bonaijre waren; egter hebben naderhand zulx onwaar bevonden. [Het vervolg toont, dat het wèl waar was]. Zedert die tijd hebben 3 Corporaalschappen burgers om de 3e wagt, dag en nagt de stad en de 3 forten in dezelve moeten bewaken.

7 dito dingsdag

Rapporteert de ruijter aan de oostpunt datter 2 barquen aan Cleijn Curaçao ten anker waren gekomen werdende gesustineert van 't france Esquadre te wezen.

8 dito woensdag

Rapport als boven dat de 2 berquen daer nog Laagen.

Omtrent deeze tijd quam de Hr. Gouvern. beneffens de Vaandrig van de militie ${ }^{1}$ ), de Raads en admiraliteijts Heeren 's avonds na bezette wagt met een lantaarn de burgers Hooftwagt en buijtenforten visiteeren of de burgers wel waren gecompareert doende vervolgens in eijgen perzoon de Hoofftronde, zijnde alstoen het [wacht] woord, de tijd is nabij, of iets dergelijx.

9 dito donderdag.

Rapport als boven dat degemelde 2 berken aan Cleijn Curaçao nog Lagen.

dito

Passeerden hier een barcq dightLangs de wal presumeerden van het frans Esquadre te wezen, om te recognosceeren [verkennen]. 10 dito vrijdag.

Arriveert een barcq van Antigue [Antigua] die door de 2 bo-

1) Willem Kerckrinck. 
vengemelde 2 bercquen wierd gejaagt was haar tegaau uit zeijlen, sneeden doe langs de wal buijten schoots verbij de haven, staken doe in de wal of zij Piscaderis wilden binnen Loopen,als wanneer van 't fort 1 schoot op haar wiert gedaan dewelke op veer na niet konden toerijken omdat het cruijt niet goet zal zijn geweest, den voornd.Engelsman gaf voor dat mons: Cassard uijt order van zijn Koning hier moest komen, was benoorden bonaijre omgepasseert en daar eenige menschen gezien wuijven met witdoeken alsof zij begeerig waren hem te spreeken, maar zeijlden voort.

11 en 12 dito

Isser niets notabels voorgevallen.

$13 \mathrm{~d}^{\circ}$. maandag.

Passeerden wederom voor bij de haven een barcq alwaar 2 schooten van 't Fort op wierden gedaan maar konde al mede niet toedragen.

$14 \mathrm{~d}^{\circ}$. Dingsdag.

Arriveert een Engelsche bercq van Antigue met Proviant.

15 do. Woensdag

Komt een Ruijter van de oostpunt rapporteeren dat boven Cleijn Curaçao 5 scheepen en 7 barken in 't Gezight waren.

$16 \mathrm{~d}^{\circ}$. Donderdag.

Met het aanbreken van den dagh wierden wij de france vloot gewaar af en aan Caraques bay, bestaande in 5 scheepen, 1 snaau [tweemastschip] en 6 barcken [Van Collen: branders], en meenden dat zij de Punt [de plaats, waar het gouvernementshuis staat; „Hamelberg” noot op bladz. 121] of de haven St. Anna wilden aandoen, maar zij hielden buyten schoots van de fortresse, lieten alle haare france vlaggen, geuzen en wimpels waaijen ende het fort gepasseert wezende, staken doe in de wal als off zij in Piscaderis off $\mathrm{S}^{\text {te }}$. Michiel wilde binnen loopen, als wanneer al de manschap zoo van de Fuijk- als Caracquesbay aan de Punt quamen afzacken, dewelke gecommandeert wierden om aanstonds naar Ste. Michiel te marcheeren, alsmeede de captijns met haar scheepsvolk als Kijsbergen [Keysberg], Schoute[n?], Verijn, [Vezcijn, kapitein van „de colonie Surinaame”?], Elias Pietersz., partij volk van Barent Nederhof [f kapitein van „de Arensberg"] en Mouliot [Moses Milliot, kapitein van „d'Anna Maria”], die alle naar Piscaderisbaay voeteerden, en de aldaar aankomende was dito vloot daar al gepasseert, gingen doe naar Ste. Michielsbay, alwaar een groote maght van volk bij den anderen was, maar bevonden dat gemelde vloot daar mede al verbij was, maar lagen doen in de wal alsof zij aan de Bullebaay wilden wezen, alwaar ook 
van onze manschap de vloot waarnamen; kort daaraan zag men ze wederom uyt de bogt komen en liepen de Westpunt van dito baay verbij naar de baay van Ste. Cruijs; des avonds wierd partij van ons volk gecommandeert naar Piscaderisbaay,omdat aldaar meest al de kragt daarvandaan was, en kreegen die nagt nieus datter 2 scheepen en al de barcquen van de france vloot reets geankert waren en de anderen ook daarmede doende waren.

Het is wel eigenaardig, dat de vijand doorvoer tot de St. Kruisbaai, waarvan, gelijk wij zagen, de versterking was overgelaten aan de planters der West-divisie.

denselfden dito

wierd bij Trommelslag geordonneert dat al de burgers Die in de stad waren met haar volle geweer zoude compareeren voor het huijs van den Capiteijn Jan Ellis, [,Notulen”: „om dit Eylandt ende Forteresse, Jaa, selfs met goedt en bloedt te deffendeeren"] van waar 3 corporaalschappen met den vaandrig Bartholomeus Tribier wierden gecommandeert in de fortresse te marcheeren blijvende de resteerende vier corporaalschappen in de stad om de hoofdwagt en de stad te obzerveeren onder den Capt. Ellis voorndt.

de prince en staten vlaggen liet men rontom de fortressen en op de gordijnen alsmede van de scheepen die in de haven waren en rondom de stad in groote meenigte waaijen, alsoff het kermis was, en waren de meeste hooftofficieren van gedagten dat de fransjes zonder slag of stoot zouden opdrossen en verbij zeijlen.

17 do. Vrijdags

des morgens kreeg men rapport als dat het gantsche Esquadre der francen aan $\mathrm{S}^{\text {te }}$. Kruysbaaij ten anker waren, des agtermiddags wierd van beneden berigt gebragt dat (door een sware buij) een schip van het Esquadre was afgedreven en dat de resteerende scheepen geweldigh op het Landt canonneerden dat egter geen schaden heeft bijgebragt, doordien de Commandeurs Gerrit van Uijtregt en andre met haar onderhebbende manschap zig omtrend een mijl van de baaij daar de francen lagen (te weten aan de Ed. compagnies plantagie de Lelienberg) ophielden.

Van Uijtregt, Commandeur over al de baaien in de Westdivisie had naar St. Kruis moeten doormarcheeren om den vijand het landen te beletten, maar was op Leliënberg met zijne manschappen gaan slapen. „Hamelberg” bladz. 121.

dito:

arriveerden een Engelsche bercq van baston [Boston] met proviant, braght nieuws datter een stilstand van wapenen was tus- 
schen Engeland en Vrankrijk zedert den len Januarij, en dat heel Engeland over hoop lagh.

dito

des naghts arriveerden een barcq in de baay van Piscaderis ten anker zijnde een Engelsman, dewelke 6 francen in hadde voorgeevende als dat hij ze in zee had vinden drijven in een vaartuijgh dat onbequaam was om zee te bouwen maar de suspicien waaren heel anders omdat hy met victualie geladen was. -

wiert den vaandrigh van de militie Willen Kerckrinck als Generalissimus en Willem de bij [Bij(e)] commissaris over den slaefsen handel, beneffens den doctor Laurentius Rudolph Horst, als gedeputeerden te velde genomineert, in welke qualiteijt beneffens haare secretarissen Everard Raax [Raacx] en Simbregt Hassen [Zimbregt Hasse] te paarde naar $\mathrm{S}^{\text {te }}$ Cruijs vertrocken, om onze manschap die aldaar in de wapenen was in goede ordre te commandeeren, ende te dirigeeren om zo 't mogelijk was, den vijand het landen te beletten, maar zij waren geland, eer den genoemde Generalissimus ende de andre gedeput. ${ }^{\text {ns }}$ te velde aan $\mathrm{S}^{\text {te }}$. Cruijs aangekomen waren, waarvan 's avonds de tijdingh aan de stad quam door gevlugte manschap, datter reeds partij van d'onze waren gesneuvelt, en klaagde geweldigh alsdat niet een droppel water hadde konnen bekoomen waardoor veele gevlugt waren.

Uit de "Notulen" valt af te leiden, dat men iemand boven Van Uijtregt wilde hebben, wat ook wel noodig is gebleken. Van Collen beroept zich er in zijn brief op, dat diens aanstelling tot "commandeur over al de baaien in de West-divisie" door zijne voorgangers (Jacob en Abraham Beck) was geschied. Zie „Hamelberg” bladz.121. De generalissimus en de gedeputeerden te velde, leden van den raad, kregen eene "Commissie in Forma" mee, „op dat een Ieder sigh het Commando.... soude onderwerpen". Zes en dertig soldaten uit het fort gingen mee "tot hun verstercking”.

Overigens loopt het verhaal op zichzelf vooruit, want de landing der Franschen vond eerst den volgenden dag plaats.

Volgens het rapport van De Bij en Horst gingen gedeputeerden te velde 's middags van den 17den op weg, bezochten zij de stellingen aan Piscaderis- en die aan St. Michielsbaai en ontmoetten Kerckrinck en het volk van de bovenbaaien op Malpais. Daar kwam tevens bericht van Van Uytregt, die op Leliënberg vertoefde, dat de vijand nog niet geland was, en hij assistentie noodig had. Van den Directeur, aan wien hij dit bericht doorgezonden had, kwam nog denzelfden avond last om de negers één uur vooruit te zenden. Men vraagt zich af, wat die generalissimus dan te commandeeren had. Tusschen 11 en 
12 uur 's nachts gingen de negers opweg, in de richting van St. Kruis, en een uur later volgde de staf, om bij zonsopgang bij St. Martha aan te komen.

18 Zaterdag

Landen de francen onder een clip zonder dat het iemant van ons (bij manquem. van goede wagt en uytkijk) haar gewaar wiert, en quamen op ons volk aan marcheeren, dewelke door 2 a 3 chargies van de onzen te rug deijnsden in welke tyd Mons. Cassard ook gequest wierd in zijn been, die daar op ook aanstonds na boort wierd gebraght de commando oovergeevende aan Mons. Candeville, die zijn volk wederom in ordre gebraght hebbende op de onzen aanquam maar door verbaastheijd van de opper en onderbevelhebberen en disordres van dezelve raakten meest al ons volk op de vlugt vermits zij haar van officiers ten eenenmaal zagen ontbloot, dewelke met verlies van sadels, degens, pistolen zo te paard als te voet reets op de vlugt en uyt het gezigt waren.

De boere Cavallerij officieren dewelke aan de baijen van St. Michiel en Piscaderis hadden gecampeert geweest, voor de comst der francen, en aldaar veel figuren met linten en stricken op reekening van het gemeen hadden gemaakt,hebben het gevegt op een genoeg samen schoot vrije bergh [op een vrijwel schotvrije berg] te paard zittende aangekeeken, en wel zorge gedragen om haar bijtijds uyt het voetpat te ruymen ende het Hazepadt te kiezen. Ende vermits geen rendevous plaats in cas van retraite was geordonneert was al het volk oover 't gantsche land verstrooijt en de meeste part wederom aan de punt geloopen, waarvan veele haar geweer hadden weggesmeeten om niet agter te blijven, ook wasser onderweg geen levensbehoeften te bekomen -

In deeze actie zijn aan onze kant gesneuvelt 1 blank en 4 zo negers als molatten,en $5 \mathrm{a} 6$ zo blanken als negers gequest en aan 's vijands zijde zijn naar gissing 15 dooden buijten de gequesten geweest.

Het is een vreemde geschiedenis. Eerst wordt de aanval met goed gevolg afgeslagen, de Fransche opperbevelhebber zelfs gewond, en dan slaat bij een tweeden aanval alles ineens op de vlucht.

De Bij en Horst en ook Van Collen geven alle schuld aan Van Uijtregt. Deze was op Leliënberg blijven slapen, zoodat Kerckrinck. De Bij en Horst op St. Martha slechts 200 man en de soldaten uit het fort aantroffen. Een boodschap naar Van Uijtregt, om naar St. Kruis te gaan, werd beantwoord met de mededeeling, dat hij eerst moest ontbijten. Toen gedeputeerden te velde op de plantage St. Kruis kwamen, bleek hun, dat de St.Kruisbaai in het geheel niet versterkt was, en er geen uitkijk gehouden werd. 
$\mathrm{Na}$ een bezoek aan de baai was het de beurt van $\mathrm{De} \mathrm{Bij}$ en Horst om te gaan ,eten en drinken" en zij deden dit op de reeds genoemde plantage. Intusschen landde de vijand, niettegenstaande Van Uijtregt aan de St. Kruisbaai gebleven was, daar en aan den Spaanschen put, wat gevaar voor omsingeling deed ontstaan. Het relaas van De Bij en Horst bevat niets omtrent het eerste treffen met den vijand, in het ,,journael" beschreven, Van Collen vermeldt wel de verwonding van Cassard en spreekt van „verslagenheid” van de onzen, maar heldert die plotselinge verandering niet op. De ,verbaastheyd" en ,disordres" van de opper- en onderbevelhebbers zullen dan ook wel de aanleiding daartoe geweest zijn. De fiskaal Van Halmale deelt ook mee, dat „de hoofden voorgingen” („Hamelberg, Documenten” bladz. 137). En toch moet het niet moeilijk geweest zijn, den vijand te keeren. De gouverneur Rodier beschreef 15 Juli 1774 de defensie van de St. Kruis-baai aldus: „Even booven deesen baaij is een plaats, het Cassard's gat genaemt.... buijten het bereijk van 't geschut van het fort op de St. Cruisbaaij.... maer ofschoon men hier op die plaats wilde landen en effectief reeds geland was, so soude twee man in staat zijn een heel leeger af te keeren. Om hier door landwaards in te dringen, is geen andere weg als een gat, waardoor man voor man moet opklouteren en doorkruijpen. Dus soude twee mannen genoeg zijn omme die geenen, die hier door soude willen kruijpen, so dra het hoofd buijten dit gat staken, die af te kappen en dus alhier het landen bijna onmogelijk is, alschoon ten tijde de franschen onder Monsieur Cassard op dit Eijland int jaar 1713 geweest sijn, de landing alhier geschied is, waarvan het ook de naam van Cassards gat gehouden heeft”(„Hamelberg, Documenten” bladz. 178).

Voorzoover niet naar „de punt” gevlucht, verzamelden De Bij en Horst met Kerckrinck hunne troepen op Malpays,.

De plaatsvervanger van Cassard wordt hier en elders ten onrechte Candeville genoemd, hij heette Bandeville.

$19 \mathrm{~d}^{\circ}$ Sondagh en 20 dito Maandag

deeden de generalissimus ende gedeputeerdens te velde, onse manschap die ooveral verstrooijt waren geweest wederom verzamelen aan de plantage genaamd Malpaijs, op den [Grooten] bergh, en wierd aldaar van de punt toegezonde een partij varsche manschap en dan nog 15 a 16 zoldaten uijt de fortresse tot secours om den vijand aldaar het verder avanceeren te beletten, nog wierd aan de burgerij in front voor de captijns-deur staande gevraagt offer onder haar geen liefhebbers waren om meede naar malpays te marcheeren, waarop voor het meeste gedeelte antwoorden van Ja, bijaldien de $\mathrm{Hr}$. Gouverneur zulx quaeme te ordonneeren mits dat 
onzen capiteijn of vaandrigh als onzen officier meede zouden uijttrecken, hetwelke door de gemelde officiers den Hr. Gouverneur gerapporteert zijnde repliceerde zulx niet en wilde ordonneeren, waarom gemelde propositie agterbleef en geen effect zorteerde, maar des avonds tot 6 uuren wierd de vrijdagse burgercorporaalschap door haaren vaandrig geconvoijeert binnen de fortresse, om tot soulaas van de sergeant en 4 à 5 soldaten, in gelijke caracter de wagt waar te neemen als 't uijtzetten van 6 schiltwagten, alle $1 / 4$ uuren een adelborst de patrouillie gedaan alsmede des morgens de poorten van de fortressen geoopent, treckende 's morgens wederom naar binnen, werdende afgelost door de assisten[ten] en schrijvers etc. ${ }^{a}$ in dienst van de Ed. Compagnie.

Zondags waren De Bij en Horst volgens hun eigen verslag naar de stad geweest om den directeur te raadplegen; 's nachts waren zij teruggekomen op Malpaijs.

dito maandag.

Arriveerden de hoeker De Post van Curaçao Capt: Jan Sijmonsz. Osslager [Afslaager] en bragt een brieff van Capt. Pieter Hansezewolt aan den Hr. Gouvern. in zee getk ${ }^{\mathbf{k}}$. behelzende dat Capt: De Veth hem hadde gecommuniceert datter stilstand van wapenen tusschen Holland en Vrankrijk was gearchordeert.

dito

Wiert goetgevonden dat de $\mathrm{E}^{\mathrm{en}}$ Bundes Schuurman $\left.{ }^{1}\right) \ldots$ een steene tranqueer zoude laten maken door d'negros, boven en langs de bergh bij de plantagie van Mordochaij de Crasto ${ }^{2}$ ) [Mordechay de Castro] met een halve maan om 4 stucken canon te planten.

dito

Lieten de Generaalisss. en gedeputeerdens te velde met alle haast zoo wel doorBlanken als negros op de [Grooten] berg van Malpaijes oover de wegh steene trancheeren maken, ende booven den afgangh of passagie naar beneden geplant 3 à 4 stucken canon 1 en 2 ponders van metaal des avonds ging een partij vrijwillige Ruijters uijt om te recognosceeren onder Capt. Balthazar Iansz. alias Balloo.

Van Collen geeft nogal op van hetgeen hij deed „om deezen post, zijnde een hooge berg met enge passage, die de vijand naar alle waarschijnlijkheid zou moeten doorgaan, met tranchees te versterken, waartoe ik alles had bezorgd wat noodig was en ook 6 metalen veldstukjes had gezonden om daar ge-

1) Waarschijnlijk de handelshuizen Brandeau en Bundes, Schuurmans Mojaard en van Pruijsen.

2) Zie de noot bij 23 Februari. 
plaatst te worden." Ongeveer 700 man zouden er aan die loopgraven gewerkt hebben.

21 do dingsdag

's morgens kreeg men tijding dat de francen in mars waaren, en continueerden om steene trankeeren aan malpayes te maken, de partij.quam wederom rapporteeren dat de Francen tot aan de plantagie van Davidt Hoffman [Daniel Hofman?] waren de opperveldheeren monsterden aan malpaijes de manschap en bevonden te zamen ruijm 700 man met de negros, omtrent 70 Engelsen wierden sonder geweer na de punt gezonden vermits haare schippers voorgaven tegens de francen niet te mogen slaan om dat die natie stilstant van wapenen met den anderen hadde hetwelk groote verwarring onder ons volk veroorzaakte, en zoo zij zeggen van de meergemelde Hooftofficieren zeer qualijk getracteert en met de tijtels van canailljes en beesten etc ${ }^{\mathrm{a}}$. wierden getituleert, den Generaliss ${ }^{s}$ : Kerkrinck en de andere mess . gaven aan een jegelijk van de zoogenaamde en gestelde $\mathrm{Capt}^{\mathrm{s}}$ : geschreeven ordres waar dat een jegelijk met zijn volk zig zouden posteeren als te weten

op het midden van de bergh van malpaijs in de weg offte passagie was het Front van de Armee, de Rechtervelugel op de bergh na de noortkant en de linkervleugel op de bergh naar de zuijdkant van het Eylandt waaroover Willem Kerkrinck de commando als chef was toevertrout mitsgaders ieder capt: oover desselfs manschap.

22 Woensdagh

's morgens omtrend 1 uur voor dag maakte men aan de Regtervleugel wederom steenetrenchen als wanneer men omtrend ten 8 uuren tegens de francen slagleeverden maar onze Generalissimus en gedeputeerdens te paard schuiven gaande veroorzaakte een generale disordre onder onze manschap en 't Gantsche leeger vlugten den eenen troep hier den anderen daar, verlatende ons canon vaandels en al de bagagie ende diverse mannen die naar $\mathrm{Ste}$ Michielsbaaij wilden marcheeren kreegen van de hooftofficieren kondschap dat het geschut aldaar reeds vernagelt was alsmede aan de baaij van Piscaderis, quamen doen met alle man hol over bol aan de punt.

Het is wel wat erg weinig wat deze dagboekschrijver meedeelt omtrent den „slag bij Malpaijs”. De Bij en Horst deelen ervan heel wat meer mee, en komen ook tot eene.andere oorzaak van de nederlaag nl. de houding der manschappen en niet die van den opperbevelhebber, diens officieren en de gedeputeerden te velde. In het kort komt hun verhaal hier op neer:

Maandags waren de troepen in compagnieën verdeeld. Van St. Michielsbaai kwamen kort daarop eenige scheepsofficieren 
met ongeveer 100 man. Deze maakten ,rumoer en ruzie” en eischten mondkost, die nog niet uit de stad aangekomen was. Hun werd toegestaan naar het huis van Pierre Veijns, daar in de buurt, te trekken, waarvan zij den volgenden dag, dus Dinsdags, toen om 4 uur bericht was, dat de Franschen reeds door de Kloof waren, werden teruggeroepen. Dien dag wordt over „veel insolentiën", verschieten van kruit en gestadig geroep om drank, geklaagd.

Het verhaal van Woensdag luidt in „Hamelberg, Documenten", bladz. 135/6 aldus:

,'s Morgens bij zonsopgang kreeg men bericht, dat de vijand wederom opmarcheerde.... een commando van 120 Elminaasche negers werd opgesteld onder het huis van Malpais, met ordre om zich stil te houden tot de vijand dichtbij zou zijn.

Ongeveer te 7 uur 's morgens kwamen de Franschen over den laatsten berg,die hen van de onzen scheidde, en stelden zich aan den voet van dien berg in slagorde. De Elminaasche negers dit ziende, wilden terstond deze vijand aanvallen en „braken uit, contrarie hunne orders”, waardoor de onzen genoodzaakt werden eenige ruiters uit te zenden om de negers weer op hun plaats te brengen. Doch hierdoor ontdekte de vijand onze steling, waarop het grootste deel der Franschen een trankeer aan de linkerzijde doorging, "met groote furie" door de mais marcheerde en onzen linkervleugel aanviel, waar geposteerd waren de scheepskapitein Pieter de Mey, Laurens Brand en Olaus Schotborgh met hun manschap, die 117 man moest uitmaken. Later bleek echter, dat de twee laatsten niet op hun post waren geweest, omdat, zooals zij zeiden, hun onderhebbend volk onwiliig geweest was dien post te verdedigen, „hetwelk anders naar alle apparentie veel schade aan de vijandt soude veroorsaackt hebben".

Vóór onzen linkervleugel hielden de Franschen een oogenblik stand en ordonneerden een gedeelte hunner troepen den berg om te gaan, ten einde de onzen inden rug aan te vallen. Van deze zijde hadden de onzen in 't geheel geen aanval verwacht, daar zoowel de kapitein der Indianen als de ruiters en de anderen, die daar bekend waren, verzekerd hadden dat men, van dien kant den berg niet op kon.

Een ander gedeelte der Franschen chargeerde „onder den bergh langs heen" zoodat, wijl ook een andere compagnie recht op onzen linkervleugel aankwam, deze zich van drie kanten tegelijk zag aangevallen". Kerckrinck met ongeveer 200 mannen daar staande, kon geen weerstand bieden, daar de matrozen en soldaten op de vlucht sloegen. „Hierdoor kreeg de vijand gelegenheid een vaandel op dien post te plaatsen bij 't geschut, ,'t welck een groote confusie omtrent de retranchement op de rechter vleugel heeft veroorsaakt", alwaar geposteerd 
waren Dom Gaspar, Lucas Lucassen en Pieter Bernard, uitmakende \pm 180 man, ,,soowel matroose als negros", en op den buitenhoek van den rechtervleugel Jacobus de Mey „met 90 Creolle als andere negros", „die naar een wijle veghtens naar de voors: retraitte mede doorgingen". Nog een half uur hielden De Bij en Horst met eenige vrijwilligers en nog eenig zeevarend volk den strijd vol, om daarna ook terug te trekken.

Met dit verslag, waarin de verslaggevers wel de mooiste rol vervulden, is niet in overeenstemming het relaas, dat Van Collen aan de X zond. Daarin wordt meegedeeld, dat de opmarcheerende vijand dadelijk aanviel, wel veel dooden en gekwetsten kreeg, maar toch den linkervleugel van de Curaçaosche troepen wist te forceeren, wat zulk eene verslagenheid in het volk bracht, dat dit naar de Punt vluchtte, ,en intusschen gingen de heeren de Bye en Horst naar de St. Michielsbaai- een sterke en voor ons zeer voordeeligepost - gaven er bevel al het geschut te vernagelen (zonder dat ik daarvan de minste kenisse heb gekregen, noch minder daartoe bevel gegeven) en kwamen daarna ook in de stad met het volk van de Varse- en de Piscaderisbaai, gevolgd door den heer Kerckrinck met de soldaten (welke de laatsten van allen zijn geweest), latende daardoor het geheele land den vijand tot prooi".

En de fiskaal Van Halmale beschrijft het gedrag der onzen als een ,hol over den bol vluchten, waarbij de hoofden voorgingen" („Hamelberg, Documenten" bladz. 137).

Nog den morgen van den 22sten kwamen de generalissimus en de gedeputeerden te velde in den Raad, "versoeckende Approbatie op hunne Verrightinge". Helaas is de beslissing op dit verzoek uit de notulen niet leesbaar. Wel dat op de vraag van den Directeur „off door syn WelEd: tot dato niets alles verright, en in 't werck gestelt is wat Immers practicabel was, tot defentie deses Eylandts en weering der vyanden". Eenparig bleek men van oordeel ,niet beter te weten off all 't noodige wat in syn vermogen was.... alle Vigelantie te hebben verright”. (,Notulen”, bladz. 114/5).

23 dito donderdagh

de francen allerwegen tot aan de punt vrij en lieber [liber] vindende zonder eenige tegenstand marcheerden tot aan de plantagie van Mordogay de Castro, Gaspar en Jzak Vooro [Isaac Foiro?] alwaar de officieren in de huijzen haar rendevous namen.

Waarschijnlijk zijn bedoeld de plantages Plantersrust enWelgelegen.

24 Vrijdagh

Kwamen de francen langs de trankeer van Mordochaij de Crasto tot in de laagte door de maijes [maisvelden] als ofze na 
motet [werf Motet] toe wilden gaen waarop van 't Front ende scheepen dapper wiert gecannonneert, nademiddag komen een partij francen aan de huijzen van Willem Motet aan de overzijde van Scharlo, alwaar een partij negros en eenige blanken op de france schooten en de francen op haar insgelijx, de Heer Gouverneur ordineert de scheepen St. Clara Georgie de $3^{e}$ en Vrijheyd om in het binnen water te halen om de francen te beletten eenige vastigheeden aldaar te maken zagen des avonds in 't land partij vieren [vuren] alsof'er brand was, des nagts waren de francen omtrent Mordochays en Gaspaar wederom gecampeert in de laagten en d'officiers in de huijzen.

25 Zaterdagh

Kreegen wij eenige gevangens dewelke voorgaven als dat de francen inde 2000 man sterk waren anderen zeyden wederom van minder,zoo dat men daer geen staat op konden maken, wij zagen zomtijds (zagen wij) eenige francen hier en daar in de vlakte als off zij plaats zogten om haar mortieren te planten, het fort schoot op dezelve als ook de schepen, 's nagts patrou.... jeerden 2 sloepen in 't vaarwater.

26 Zondagh

zag men de france nog in de vlakte, waarop door 't canon van de fortresse 't fortje Oranje en 't schip d'Adrichem dapper wiert geschooten omtrend de middag comt'er een afgezant met een tamboer van de francen om de stad het landt fortresse en scheepen voor haaren Coning op te Eyschen, dog kreeg van onzen gouverneur tot antwoort als dat hij tydinge hadden dat wij[er?]zeekerlijk stilstand van wapenen met den anderen was gecontracteert, maar ingeval zij het niet wilde gelooven dat ze konden haar gang gaan datter niet als kruijt en loot voor haar ten besten was, waar op den afgezant weder vertrok, nademiddagh zagen wij als dat de francen doende waren om een batterij op te werpen voor haar mortieren alwaar wederom dapper op geschoten wiert als wanneer een tweede gezant met een Tamboer oover quam met verzoek om zoo lang op te houden met schieten tot datter antwoort gekomen was van den Generaal Mons. Cassar[d] gequest aan boort van't schip LeSemenaire [Téméraire] aan StCruysbaay.

Over deze dagen is de dagboekschrijver wel wat erg sober. De notulen van den Raad van 24, 25 en 26 Februari 1713 bevatten uitgebreide mededeelingen over vergeefsche pogingen om vrijwilligers te bewegen den vijand aan te vallen en hem te beletten in Piscaderisbaai kanonnen te landen. Het is te begrijpen, dat men in die omstandigheden den volgenden dag 
niet durfde aannemen een voorstel van de schippers der Hollandsche schepen om een algemeenen uitval op de Overzijde te doen.

Volgens den brief van Van Collen („Hamelberg” bladz. 123) kwam de hierboven bedoelde afgezant, Le Chevallier Legondes, den 27sten 's morgens vroeg. Daar vindt men ook vermeld, dat de gouverneur het bericht van den wapenstilstand op $22 \mathrm{Fe}-$ bruarie met schipper Jan Swart had ontvangen van kapitein Pieter Hansz Zeewold, die 't weer gehoord van kapitein De Velt. Dat is dus een ander bericht dan het hierboven op 17 Februari vermelde. [De „Notulen” noemen als tweede afgezanten met den tamboer:Bruiel, majoor-generaal, en Belgens, majoor van Martinique. Laatstgenoemde bleef in handen der Curaçaoenaars, die den kapitein Jan Martin afzonden, om toe te zien, dat de Franschen hunnerzijds ook de voorbereiding der vijandelijkheden zouden staken].

27 Maandag.

Komt onze ostagier [gijzeaar] met een derde afgezant van de francen terug dewelke uijt de naam van Mons. Cassard voor de $2^{\mathbf{e}}$ maal de stad, land etc ${ }^{\mathbf{a}}$. komt op te eijssen met de ordinaire france dreijgementen, waarop als vooren wiert ten antwoord gegeven niet als kruijt en loot voor haar ten besten was, welk antwoord de gantsche burgerije Laudeerde en wel naar haar zin was waarop den france afgezant wederom vertrok. Kort daar aan begonnen wij als voren sterk te canonneeren, ende wierden resiproque gefiliciteert met 34 Bomben van 30 à 80 ponden ijzer, dewelke geen van allen zonderlinge schade causeerde zoo in de stad fortresse als schepen; nademiddag hield de vijand wat op van bombardeeren maar wij cannonneerden egter continueel des 'savonds omtrend 9 uuren wierden wij wederom gesalueert met bommen dat den geheelen nagt continueerden ter zomma van omtrend 60 stux dewelke weeder geen werkelijke schaden hebben toegebragt als het inslaan en onder de voet werpen van twee kleyne huijzen en een pakhuys daar cacao in lagh, dien nagt waaren de 7 corporaalschappen borgers alle op de wagt en in haar volle geweer.

Volgens de „Notulen” was 't weer de majoor-generaal Bruiel, die als afgezant kwam. Hij had den bij „Hamelberg Documenten" op bladz. 114 afgedrukten brief van Cassard bij zich, waaruit te lezen valt, dat de „ordinaire france dreijgementen” bestonden in een bombardement gedurende dag en nacht, totdat Cassard, van zijne wonde hersteld, met vier barken soldaten aan het beleg zou komen deelnemen, tenzij men de voorkeur mocht geven aan eene redelijken afkoopsom. Het bovenbedoelde antwoord vanVan Collen vindt men ook bij „Hamelberg Documenten" t. a. p. 
28 dinsdag.

Continueerden de france met bombardeeren tot ten 7 uuren in de morgenstond met 14 zoogenaamde bomben dewelke met beeter observatie geworpen zijnde wel de meeste schade en ruine hebben bijgebragt als het demolieeren en onder de voet werpen van het huijs van de hr. Gerard Luls..... doen bewoont bij de $\mathrm{Hr}$ Willem de bij commissaris over de slaafzenhandel, alwaar 2 negerinnen en 3 kinderen dood bleeven en 7gequesten Item in 't huijs van Mevrouw de Wede. Kerckrinck.... viel een bom boven door het dak int' pakhuijs aan de kant van de fortresse, alwaar 17 francen gevangen waren geplaatst die door de burgerwagt wierden bewaakt, welke bom 1 van dito gevangen doode en 2 swaar questen die kort daarna ook zijn gestorven, en dan nog 7 daar van wierden gequest de deur van ' gemelde pakhuijs borst door de kragt van de bom oopen dat al de gevangenen daar uijt liepen dewelke wederom op een na wierden gevangen en onder het huijs van de campagneur [compagnie?] bewoont bij den fiscaal Jan Frederik van Holmaat [Halmael ot Halmale] gebragt wierden en de gequesten mede in 't hospitaal onder 't zelve huijs en vielen eenige bomben op het pleyn in de fortresse waar van een swaarlijk queste de vrouw en 't kind van een bosschieter waaraan ook zijn gestorven, zo dat in alles 108 bommen door de francen uyt 3 mortieren zijn geworpen, welke mortieren waren geplant in de plantagie van Guadelupe [Mundo Nobo?] op de roode weg aan de zeekant - verscheijde stucken van bommen die in de lugt borsten vloogen de geheele stad oover en in verscheijde huijzen van de burgers zoo door de pannen combuijzen als anders, nog een stuk van een bom viel bij het schip d'AnnaMaria ophet hoofd van een $\mathrm{S}^{\mathrm{t}}$. Thomas - schipper genaamt Packquereaux die wijnig uuren daaraan van storff en door Jongmans van de Vrijdagse wagt wiert begraven, Jeronimus dures [Durer] schoonzoon van frank Kinndgem [Kinnegem] wiert mede door een bom voor de hoofdwagt vallende swaarlijk gequest ende aanstonds daaraan overleeden, int'Pakhuijs van Elias Panera [Parera?] wierden 2 negerkinderen onder de cacao doodgevonden en 1 negerin met 1 kint gequest, alzoo door 't vallen van een bom in dito pakhuijs de zolder daar de cacao op lag was ingestort. Verder nog eenige negros die door de bomben ligte quetzuren hebben ontfangen.

De onbekende dagboekschrijver telt op 27 en 28 Februari nauwkeurig $34+60+14=108$ bommen; Van Collen spreekt in zijn brief van 115 stuks. Hij voegt eraan toe, dat onder het bombardement het grootste deel der burgerij met vrouwen en kinderen de stad uitgingen en op het Steenenpad [Pietermaai] 
tenten opsloegen, ,alwaar zij door den vijand konden worden gezien en dezen zoo in de gelegenheid stelden, om, door hen gevangen te nemen, (hetgeen door een omtrekkende beweging gemakkelijk [sic?] kon worden bewerkstelligd) ons tot overgave te dwingen”. „Hamelberg” bladz. 124. Zie hieronder ad 1 en 2 Maart.

$\mathrm{d}^{0}$.

voordemiddag waaren eenige francen bij motet en in de vlakte als of zij aldaar eenige werken wilden maken maar door het cannonneeren van de scheepen die binnen lagen waaren zij geobligeert om te retireeren, wij kreegen wederom eenige gevangens, nademiddag komt voor de $4^{\mathrm{e}}$ maal een afgezant en trompetter van de francen om te vragen of men wilde capituleeren eyschende 300000 pesos en al de negros slaven mitsgaders al wat boven water dreef te weeten d'schepen en bercquen met haar Ladinge waarop de Heer Gouverneur en Raaden rezolveerden de Officieren van de burgerij en de sergeanten mitsgaders d'capitijns van de scheepen te laten boven roepen en communiceerden haar den den eijsch door de francen gedaan en proponeerden of het niet beeter en waar iets te geeven als alles te verliezen, te meer de vierpijlen [vuurpijlen] vrij wat schrik en alteratie hadden gecauseert, maar de meeste magt van de burgerij en Capitijns van de scheepen waren daar gants niet toegenegen en zeyden abzoluijt als dat ze niet een stuyver voor capitulatie aan de francen wilden geeven alzoo men door haar heen en weder loopen wel konde afmeeten dat zij met het schieten van bommen haast zouden gedaan hebben, ende men ook wel hadde gezien dat een van haare mortiers moeste onbruijkbaar geworden weesen alzoo de meeste bommen door twee mortiers alle $\frac{1}{2}$ quartier uurs wierden geworpen 2 naar malkanderen -

Den francen afgezant bemerkende dat de hr. Gouverneur en Raden wel genegen waren om een accoord te willen aangaan verzoght om stilstand van wapenen voor 24 uuren het welk hem wiert toegestaan als wanneer men met cannonudeeren en bombardeeren aan weerskanten ophieldt.

Het bovenstaande is in lijnrechten strijd met Van Collens brief en met de „Notulen”, zeer ten nadeele van „Gouverneur en Raden".

Vooreerst wat de eisch van Cassard betreft: hier wordt gesproken van 300000 Pesos, alle negerslaven en de schepen met hunne lading, Van Collen noemt alleen 400000 Pesos. De „Notulen”, die eenzelfde bedrag noemen, echter alleen als schatting van den Franschen afgezant,doen het voorkomen als- 
of het voorstel om een wapenstilstand van den Gouverneur en Raden met de "Coopluyden en Borgers" uitgegaan is.

Toch kan men uit Van Collens brief wel afleiden, dat de kapiteins der schepen die zeer nauw bij de capitulatie-voorwaarden betrokken waren, en misschien ook de officieren, anders wilden dan dezen, want de Gouverneur motiveert zijn later ingaan op de „rantsoeneering" uitdrukkelijk met een beroep op den onwil der soldaten en vreemde matrozen en de ongehoorzaamheid der schippers met uitzondering van Van de Wetering, Keijsbergen en Strijd.

Uit de „Notulen” kan men voorts afleiden, dat Gouverneur enRaden weer de waarschijnlijkheid van vredesluiting tusschen Holland en Frankrijk hadden opgeworpen. De Fransche afgezant, die aan den avond van dien dag kwam met Banderville's antwoord, de heer Calquier, gaf te kennen, dat de Franschen voor dat geval de ontvangen brandschatting wel zouden willen terugbetalen „Ingevolge, soo als sulcx door wederseyds ministers in Europa soude beslooten zyn".

$\mathrm{P}^{\mathrm{mo}}$ Maart.

Woensdag maakten de scheepscapiteijns met haar volk een batterij van 6 stucken canon 6 ponders op de bergh van Scharloo dewelke door de hoogte correkt flanqueerde in de werken van de francen daar de mortieren geplant waren, ook belette hetzelve dat de vijand bij motet en in de laagten geen nieuwe werken of sterktens konden maken, Twee Raaden gingen dito baterij visiteeren en was ook volkomen van haare approbatie ende de $\mathrm{Hr}$. Gouverneur prezenteerde aan de Capt. 2 stucken canon 12 ponders om aldaar te planten, maar als wanneer dezelve wierden geeijscht kreegen tot antwoord dat men daar mede tot morgen zouden wagten, dien dag kreeg men wederom 31 gevangens maar door ordre van hoogerhand moest men dezelve wederom largeeren [om den wapenstilstand?].

des avond naar het Trommelslaan van de taptoe komt voor de $5^{\mathrm{e}}$ maal twee afgezanten met 1 tamboer verlieten de capitulatie voor $\mathrm{P}^{8} .200000$ maar moesten zonder eenig accoort wederom vertrecken met recommandatie van zoo laat in de nagt niet wederom te komen.

Deezen selven dag omtrend de middagh gingen al de vrouwen Jonge Dogters en kinderen de stadspoor uijt zo Christenen als Jooden, zoo rijken als armen en lieten aldaar tenten opslaan van Jan Crediet (die meest te grond is [?]) af tot aan Altena toe om in geval van een nieuwe bombardeering wat uijt de weg te wezen en waaren diverse familien heel naar de fortresse van Caraquesbay gevlugt,. 


\section{$2 \mathrm{~d}^{\circ}$. Donderdagh}

bragt ons volk wederom 4 gevangenen arriveert een Engels schip van boston geladen met hout en victualie. Kort daaraan komt voor de $6^{\mathrm{e}}$ maal wederom een afgezant [volgens de „Notulen" twee afgezanten, Calquier en luitenant De Spenais of d'Espinay] met een tamboer en eijscht 150.000 pesos, waarop de hr. gouvr. en weijnig uijt den raad (etc $\left.{ }^{a}\right)$ de capit. en eenige burgerofficieren en coopluijden geweldig aanpresten dat men de francen zoude zien af te zetten met een Goudbeurs van P 60000 het welk ook aan den afgezant wierd geprezenteert, maar zouden dien avond niet accoort komen zoodat den afgezant des nagts in de fortres slapen bleef, gaande de capt. Ian Martijn [Martin]naar de werken van d'francen om het zelve te bezien alzoo zij voorgaven van bomben als andere krijgsmaterialen nog rijkelijk verzien te wezen, om ons werkelijke schaden en ruinen te konnen aandoen, aan d' ooverzijde komende wierd aanstonds geblind en in 't quartier van Mons. Bandeville gebragt wel getracteert en des nagts geslapen.

De vrouwelijke sexe en kinderen hiervooren genoemt nog buijten de stad in haare tenten resideerende, zoo komter een van ons volk met een paart te post aanrijden uijt het quartier tegens den avond, makende een looze alarm dat de francen waaren omgemarcheert en tot aan de zoutpan [de „Saligna”, voorbij „Hel”] genadert, hetwelk zulk een groote verslagentheyd in het femenine leeger veroorzaakte dat alle hol oover bol naar de stad retireerden agterlatende meest al de bagagie zommige kinderen, muylen en andere ingrediënten meer, en gingen dien nagt ieder in zijne eijgen huijs slapen vermits zij de stilstand van wapenen vernamen en dat de capittulatie zeer apparent zoude getroffen werden.

deeze tijd moesten de burgers 2 nagten en een dagh zijnde 60 uuren naar den anderen de wagt houuen. Eenige Jooden zo men zeijde gingen in vrouwenhabijt buijten de poort in de Tenten, en andere wierden aldaer in sluijt bennen [waschmanden?]gebragt [om de wacht te ontloopen?]

De „Notulen” van 2 Maart zijn zeer uitvoerig en met reden, want zij moeten verklaren, waarom de Raad besloot op de capitulatie in te gaan. De afgezanten zouden gevraagd hebben 300000 Ps., minstens 250000 . Als redenen voor het tegenbod van 50000 à 60000 Pesos worden genoemd: de onwilligheid van het krijgsvolk, de schrik onder de burgers en het vluchten van „Mans [sic!], vrouwen en kinderen", de mogelijkheid van eene landing der Franschen aan den Waterkant, en de hoop op terugbetaling van de brandschatting als er wapenstilstand 
tusschen de Republiek en Frankrijk zou blijken te zijn gesloten ${ }^{1}$ ).

Wat in het dagboek wordt meegedeeld lijkt allerminst op de eenparigheid van den Raad, burgers en kooplieden, waarop Van Collen zich beroept. In iedergeval bestond die eenstemmigheid volgens de "Notulen" zeker niet over de vraag, wat moest gedaan worden, als de Franschen de 60000 zouden weigeren: zes wilden dan de onderhandelingen afbreken, drie daarentegen een hooger bod doen. Onder deze laatsten was de burger-officier Tribier. Op dezen avond te 10 ure moet toen het bezoek van ,verscheidene kooplieden en ingezetenen, met onzen secretaris”, waarvan Van Collen spreekt („Hamelberg” bladz. 215), hebben plaats gehad met het bekende gevolg, op den volgenden dag, alweer ,, met generale toestemming van den Raad en de voornaamste kooplieden, burgers en opgezetenen".

Het is ook wel opmerkelijk, dat wat de Gouverneur (ad 28 Febr.) als een feit vermeldde, hier nog niet eens van het vermelde „looze alarm” deel uitmaakt.

3 Vrijdagh

Komt Capt. Jan Martijn uijt het Campement van de francen wederom te rugh dewelke rapporteerde dat men hem de 3 mortieren daar de bommen uijt geworpen waren hadde laten zien dewelke zo zij zijden nog alle in goede staat waren, en dan nog 2 ooverdekte hoopen met zo de francen voorgaven, 80 gevulde en 100 ongevulde bomben, dog wierd hem niet gepermitteert het dekkleet open te slaan, om dezelve te bezien, waarom bij de burgerij gesustineert wiert al het zelve maar fluiten [of fluten d.i. praatjes maken, iemand iets op de mouw spelden] te wezen om haar te misleyden en tot een capitulatie te doen resolveeren, waarop, de hr. Gouverneur zijne raaden burgerofficieren (zoo luijtenant vaandrigs als sergeanten) de meeste Coopluijden en voornaamste opgezetenen mitsgaders de Capt. ${ }^{\mathrm{s}}$ van deScheepen en Schippers van de barken door de sergeants van wapenen liet boven roepen om nogmaals haare zentimenten te hooren waarop het meeste gedeelte ten antwoordt gaven dat zij niet konden zien dat men voor als nogEenige capitulatie aan de france zouden toe staan, alsoo er tot dato nog geen merkelijke ruinen aan de Stadt nog fortresse was toegebragt ende ook geen volk als $\mathrm{p}^{\mathrm{r}}$. ongeluk van bomben waren gesneuvelt, en dat men ons beste zouden doen om haar in kruijt en loot de Capitulatie te zullen voldoen, al het welke het zij door vreeze voor de vierpijlen en verdere rampen voortekomen, door de Heeren Gouv ${ }^{r}$. en Raden eenige Coopluijden en opgeseete-

1) De vrede werd echter eerst 11 April 1713 gesloten. 
nen, wiert gedisapprobeert ende accordeerden vervolgens met de francen voor een somma van 115000 pesos van agten te betalen $1 / 3$ in Contanten en victualie $\frac{1}{3} \mathrm{e}$ in slaven en de rest in cargazoenen [scheepsgoederen],binnen den tijd van 14 dagen te leeveren, ende in cas van eenig dilay [delai-vertraging] te betalen alle dagen duijzent pezos, waarop aanstonds door den raadt 10 commissarissen wierden gesteld (om alle ende een iegelijk burger opgeseten en Capts.van de scheepen te quotiteeren wat zij bij provisie moesten betalen om daar uijt de bovengemelde 115000 pezos contributie en dan nog 3500 pezos aan onkosten te vinden en te betalen). Namentlijk Willem Kerckrinck- Willem Meijer, Thomas BundesBartholomeus Tribier, Laurens van Bambergen, Pieter Moijaart [Mojaard],Nathaniel Ellis en david Redoch [Redog] van de Christenen en Mordogaij de Crasto en Gabril Levi (Levy] van de Joden, welke in een lijste ${ }^{1}$ ) gemaakt zijnde wiert een ieder een kleen snippertie papier thuijs gebragt waar op simpelijk geschreven stond den naam en hoeveel hij bij provisie getaxeert was, al het welk zonder de minste Examinatie en Verhooringh geschiet is, daar op wiert defacto bij placcaat gepubliceert dat een ijgelijk zyn quota waar op hij getaxeert was binnen den tijd van 2 maal 24 uuren zouden komen voldaan aan daar oover gestelde Commissarissen ten getale van 7 of 8 perzoonen. En de wiert alsdoen door de france officieren die met meenigte aan de punt quamen passen gegeven dat een ieder Liber en vrij uit land na haare plantagien konden gaan en wederkeeren.

Volgens de „Notulen” werden de kapitein Jan Martin en Zimbregh [Zimbregt] Hasse als gijzelaars voor de betaling aan de Franschen gegeven.

De vraag of ook de eigendommen der Compagnie moesten deelnemen in den hoofdelijken omslag werd bevestigend beantwoord.

4 en 5 dito

Gaan veele burgers als andre Lieden naar de ooverzijde intCampement van de france om te bezien hoe het aldaar gestelt was, en volgens het zeggen van diverse waren deze mortieren onbruykbaar en de bomben onbequaam om geworpen te konnen werden, alles hetwelke dien avond aan boort van 2 barken die aan Piscaderisbay Lagen geembarqueert wierdt.

6 dito Maandag

kwam er rapport aan de punt datter beneden bij Mons Cassard tot secours 2 barquen van $\mathrm{S}^{\text {te }}$. Domingo met omtrent 400

1) $\mathrm{Bij}$ „Hamelberg Documenten” bladz. 116-129. 
man waaren aangekomen, dog vermits de affaires met hetEijland al was gereguleert ordonneerde $\mathrm{d}^{\text {to }}$. Cassard dat zij maar konden vertrecken.

De france officiers verhalen aan ons zo in haar Campement als in de stadt datter daags voor de capitulatie een brief van Mons. Cassard in t'france Campement was gekomen waar in denzelve ordineerde dat zij met alle magt zouden opbreeken en de stadt verlaten, en hadde tot dien eynde al een schip in piscaderisbaaij gezonden om partij daarvan af te halen.

7 dito Dingsdag

Komt er van beneden tijding dat de $2 \mathrm{~S}^{\text {te }}$ domingosche barquen partij negers roofden en omtrent ten getale van 30 stux aan haar boort voerden hetwelk aan Mons. Cassard verzogt wierd omt beletten, alsmede datter geen negers aan boort van de scheepen of bercquen mogten aangehouden werden waarop hij ten antwoort gaf dat de voorsz. St. Domingosche berquen buyten zijn Esquadre waren,en dat de Hr. Gouvern.: ind' baijen wagten konde stellen om zulx te prevenieeren en voor te komen dog dat de negros die men aan zijn boort konde agterhalen, voor ieder van dezelve 120 pezos zoude betalen alsoo volgens ordre des konings degeene die haar onder zijn vlagge begeeven hadde niet wederom vermogt relaxeeren.

8 dito Woensdag

de francen brengen haar artillerij etc ${ }^{\mathrm{a}}$ aan boort en defileeren naar haare scheepen in goede ordre.

9 dito Donderdag

Eenige france officiers komen in de stad en promeneeren in Comp: van den fiscus rontom de batterijen vand' stad en fortresse alsmede buijten de poort op het steene padt[Pietermaai]tot haare speculatie.

10 d0.-14

Niets notabels gepasseert, als datter ordre wiert gegeven van hogerhand om de stadspoort geslooten te houden en de fransies beletten de batterijen etc $^{a}$ te laten passeeren.

$\mathrm{d}^{0}$.

wierd partij victualie en cargazoen etc ${ }^{\mathrm{a}}$ aan de fransies gezonden tot betalinge vand' constributie op reekening.

15 a 18 do.

Niets bijzonders voorgevallen als heeden $18^{\mathrm{e}}$ arriveert een Engelse barcq van Nevis, confirmeert de stilstand van wapenen. do. 
vertrecken de capergasten met haare bercquen en de oorlogscheepen van het france Esquadre zoo men zegt direckt naar Vrankrijk waar mede overgaat Mons. de Chaine ostagien van Suriname.

$\mathrm{d}^{\circ}$.

Mons: Bandeville met omtrend 25 a 30 andre officieren wierden boven magnifiecq getracteert, en wierden savonds op haar vertrek met 9 canonschooten geconduiseert.

De „Notulen” vermelden hiervan begrijpelijkerwijs niets. 't Is dan ook wel heel erg, Wel vindt men twee dagen later aangeteekend, dat Calquier en De Spenais een "praesent" van 1000 Ps. ter verdeeling kregen voor hun goede dienst" bij het helpen „féciliteren" van „het ffournissement van het geslooten Accoort van Contributie".

19 à $21 \mathrm{~d}^{\circ}$

passeerden niets notadignum als dat heeden 21 arriveert de snaau. De Amsterdamse galij Capt: Gysbert Harsmoen van Amstd $^{\mathrm{m}}$. en laast van Madera.

22 Woensdag

Wert de afreekening wegens de Contributie van $\mathrm{P}^{\mathrm{s}} .115000$ met de fransies opgemaakt en zoo men zegt betaalt zoo in slaven contanten victualie en cargazoen goederen etca.

$\mathrm{d}^{\mathrm{o}}$.

Vertrekt uijt $\mathrm{S}^{\text {te }}$. Cruijsbaij Mons, Cassard met schip Le timmeraire [Le Téméraire] zeer lek zijnde latende voor de ontfangene contributie 2 france ostagiens met namen Angier en Lombart zoo men zegt van zeer geringe Exttractie.

Deze gijzelaars waren borg voor de terugbetaling der brandschatting in geval later blijken mocht, dat er een wapenstilstand was geweest tusschen de Republiek en Frankrijk ten ten tijde van den aanval op Curaçao.

\section{3 en 24}

Niets bijzonder voorgevallen als dat Mons: Chabert [de spion van 3 Februari] naar Laguayre is vertrocken.

De „Notulen” van 13 Maart maken ook nog melding van een zekeren Jan Haack ,zynde geboortigh van Amsterdam, en lange van dit Eylandt gevaren hebbende", die de Fransche vloot ten anker zou gebracht hebben.

25 Zaterdag

gaan van hier voor de Eerste mael naar de france invasie 4 barcquen per negootie na de Cust van Caraques 
26 a 31

Niets notabels gepasseert als dat op 27 en ultimo 2 barcquen van St.Thomas arriveeren confirmeerende de tijding van stilstand van wapenen en ook dat het zeer apparent vreede was.

$\mathrm{P}^{\mathrm{mo}}$ a 12 April.

Sonderlings niets voorgevallen alsdat op heeden $12^{\text {de }}$ van Laguayre arriveert des Ed. Comps ${ }^{8}$. barcq en nog een van 1 frans assiento Mons. Petit door Chourio [zie 3 Febr.] afgeladen.

13do. Donderdag.

arriveert de kleijne Compagnies bark van (zoo men zegt) bonaijre [Bonaire], egter wiert contrarie gesustineert dat hij direkt van Laguayre was komende volgens rapporten van die daargekomen waren.

Eijnde.

Dordrecht December 1923.

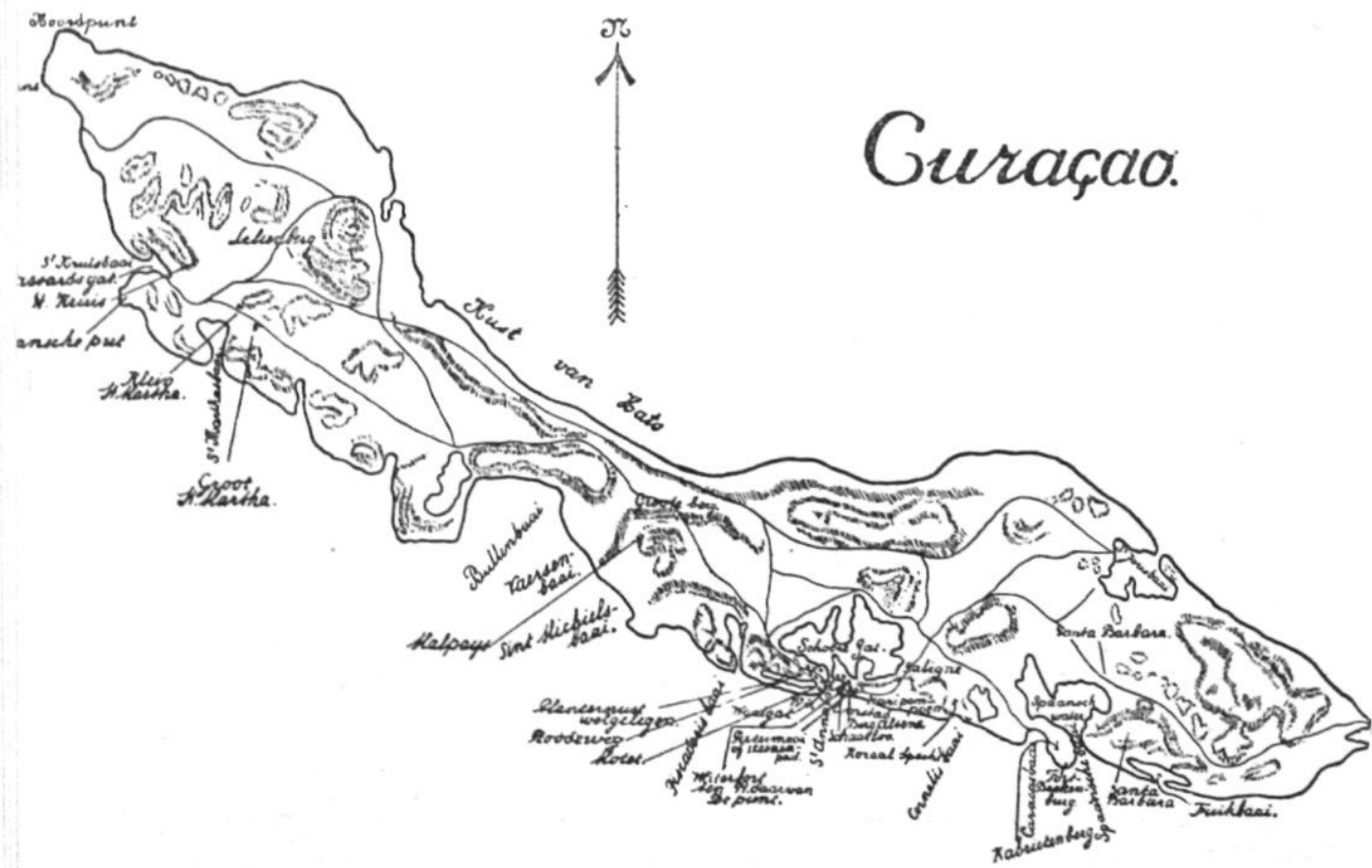

